\title{
Buffer Zone Resources and Community Conservation: A Case Study of Handi Khola Buffer Zone User Committee, Parsa Wildlife Reserve
}

\author{
Aruna Thapa ${ }^{1}$ and Dinesh R. Bhuju ${ }^{2}$ \\ ${ }^{1}$ Central Department of Environmental Science, Tribhuvan University, Kirtipur,Kathmandu \\ ${ }^{2}$ Nepal Academy of Science and Technology (NAST), Khumaltar, Lalitpur \\ e-mail:magarat09@gmail.com
}

\begin{abstract}
The present study was carried out to understand ecology of forests and social strata in Handi Khola Buffer Zone User Committee of Parsa Wildlife Reserve in Central Nepal. Methods used were stratified random sampling of household economics with questionnaire survey for socio-economic information and quantitative and qualitative analysis for vegetation study. Seventy two households were studied in-depth through household surveys. Vegetation ecology and forest resources were studied in Rakshaniya, Dhaneshwor, Laamitar and Masine forests of the BZ, totaling 37 sample plots. The study recorded a total of 36 tree species from 19 families. Shorea robusta was the dominant tree species in the community forest with highest important percentage, standing volume, biomass and sustainable fuel wood yield. The study area was sufficient to fulfill the demand of the fuel wood and timber in a sustainable way but annual demand of fodder (9640.54 tons/year) outstripped the annual sustainable supply of fodder (409.41 total digestible nutrient in tons/year). Thus, community forest was insufficient to provide the resource equally to all seasons and its unequal distribution compelled the locals for illegal extraction of resource showing some pressure on the reserve. In addition, large-scale human interference (Cut Stump Density-39.56/ha and Live Tree Density-58.11/ha) in community forest questioned the endurance of buffering potential and biodiversity conservation.
\end{abstract}

Key words: demand and supply, livelihood, forest resources, anthropogenic pressure

\section{Introduction}

The buffer zone program is an incremental step in effort to employ participatory methods and collaborative management in biodiversity conservation, and to shift the paradigm of 'Protection of the park from the people' towards 'Protection of the park through the people' (Budhathoki 2005). The concept of buffer zone, besides calling for the sustainable utilization of forest resources, also necessitates environmental conservation within the zone. However, extraction of resources from the protected areas without sound guidelines results in depleted natural resources and antagonism between local people and park personnel (Sharma 1995). Thus, on one hand, there is an urgent necessity to protect natural areas, on the other, the livelihood needs of local communities have to be duly considered without which any efforts towards protected area conservation is bound to fail in the face of poverty stricken conditions of local communities.

Nepal entered into the new era of conservation with the promulgation of National Parks and Wildlife Conservation Act 1973, which provided a basis for the 
establishment of protected areas and conservation of wildlife and their habitats. The establishment of Chitwan National Park (CNP) in the year of 1973 materialized the nature and species conservation movement. Since then Nepal has established an extensive network of protected areas, now covering a total area of 33,073 $\mathrm{km}^{2}$ (22.5\%) of the country's total land. Currently this included ten National Parks, three Wildlife Reserves, six Conservation Areas, one Hunting Reserve including "buffer zones" of ten National Parks and Reserves (GoN/DNPWC 2009). Though protected areas are one of the conservation's oldest devices and have become the cornerstone of biodiversity conservation, they are, continually under threat from growing human population (Wyne 1998).

The objectives of this study were to contribute acquaintance about biodiversity conservation by assessing socioeconomic structure, community activities and natural resource status of Handi Khola Buffer Zone User Committee of Parsa Wildlife Reserve, Nepal.

\section{Methodology \\ Site description}

Handi Khola VDC with an area of $106.6 \mathrm{~km}^{2}$ lies in Makawanpur district in the Narayani Zone of Southern Nepal (Fig.1). Lying to the southwest corner of Makawanpur district, Handi khola VDC borders with Manahari VDC to the west, Padampokhari VDC to the east, Basamadi VDC to the north and dense forest of Parsa Wildlife Reserve, Parsa to the south. This VDC is drained by the Rapti River through the rivulets like Twangra khola, Masine khola, Handi khola and Thado khola. The climate is sub tropical monsoon type. The study area include 5,6 and 7 wards where there were four community forests covering an area of 1204.2 ha (Fig.1). All these forests are joined with each other but only river is responsible for their separation. These forests are natural forest. Shorea robusta is the dominant species followed by Terminalia alata, Lagerstroemia parviflora, Semecarpus anacardium, Careya arborea, Schima walichii, Terminalia bellerica as co species. Some of the wildlife found in the forest was Panthera tigris, Axis axis, Rhinoceros unicornis, Sus scrofa, Panthera pardus, Hystrix indica.

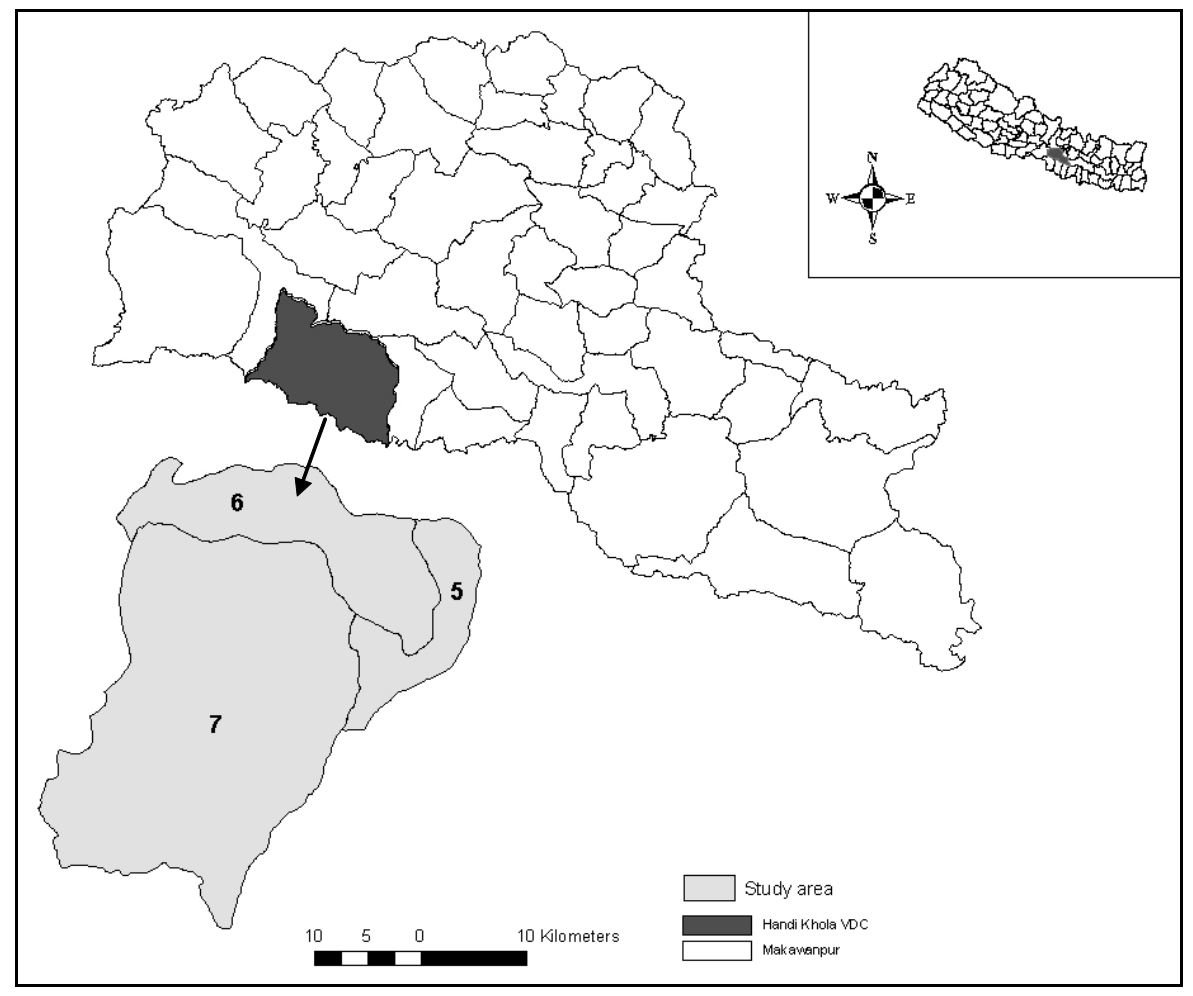

Fig. 1. Map showing study area 


\section{Field survey and data collection}

The field study was carried out during March and April in 2009. For the household socioeconomic survey, the stratified random sampling was applied on the basis of settlement size. The sample size (72 households) of the household in the study area was determined by using statistical formula (Arkin \& Colton 1963). Likewise, the systemic sampling was used with intensity of $0.5 \%$ to analyze the vegetation of the forest. The sampling points were generated within the patches at an interval of 500m using Geographic Information System (GIS) and were determined by tracking with Global Positioning System (GPS).
A total of 185 plots were laid for the vegetation survey. Each sampling plot was measured through quadrat method. These included 37 plots $(20 \mathrm{~m} \times 20 \mathrm{~m})$ for tree species $(\mathrm{DBH}>10 \mathrm{~cm})$ (Fig.2), within tree plot in diagonally opposite corner (NE \& SW), 74 plots for shrubs $(\mathrm{DBH}<10 \mathrm{~cm})$ with plot size $5 \mathrm{~m} \times 5 \mathrm{~m}$ and within shrub plot, 74 plots for herbs (height $<10 \mathrm{~cm}$ ) with plot size $1 \mathrm{~m} \times 1 \mathrm{~m}$ were laid down. Height and dbh of all trees were measured with the help of clinometer and dbh tape respectively. Sapling (greater than $1 \mathrm{~m}$ height and having dbh less than $10 \mathrm{~cm}$ ) and seedling (height 30 $\mathrm{cm}$ to $1 \mathrm{~m}$ ) were counted in sub-plot of $5 \mathrm{~m} \times 5 \mathrm{~m}$ inside sampling plots.

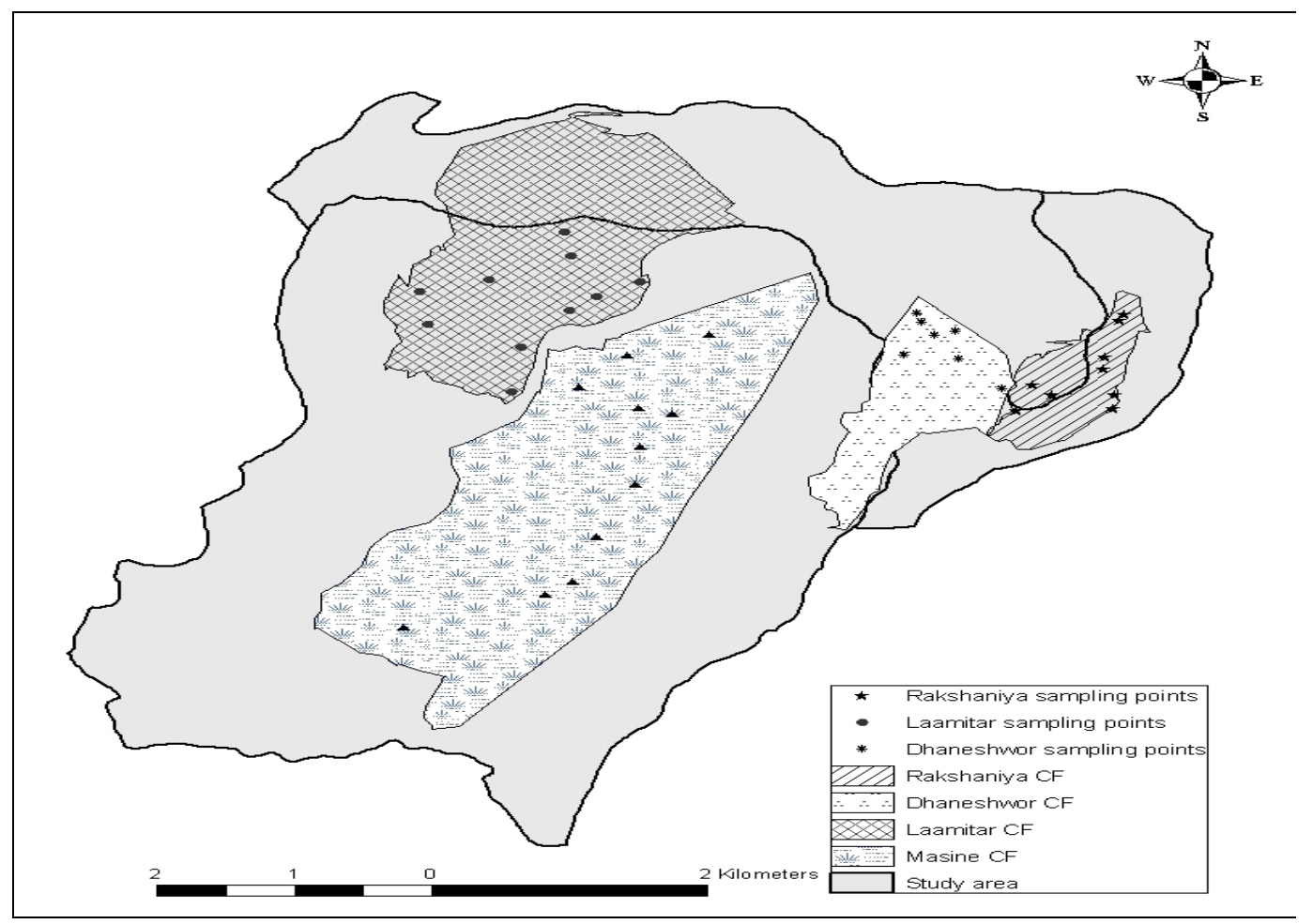

Fig.2. Forest and its sampling points

Number of cut stumps of tree species with height and circumference at top and lopping percent of tree species were noted in $20 \mathrm{~m} \times 20 \mathrm{~m}$ plots to specify anthropogenic interference, grazing pressure and management practice. Data were analyzed to calculate density, relative density, frequency, relative frequency, dominance, relative dominance, Importance Value Index (IVI) following Kent and Coker (1998) and Odum (1996). For estimation of volume and biomass, "Volume
Equations and Biomass Prediction of Forest Trees of Nepal" developed by Forest Survey and Statistical Division (FSSD 1990) was used. The volume of the tree components was calculated by using following equation:

$$
\ln (V)=a+b \times \ln (d)+c \times \ln (h)
$$

where, $\mathrm{V}$ is total stem volume with bark $\left(\mathrm{m}^{3} / \mathrm{ha}\right), \mathrm{d}$ is diameter of tree at breast height (m), $h$ is tree height (m) and a,b,c are parameters estimated. Biomass of the 
tree components was calculated by multiplying volume by wood density which was obtained from Master Plan for Forestry Sector Nepal: Forest Resources Information, Status and Development Plan (MOFSC 1988).

Shannon-Wiener's Index was calculated to measure species diversity. The Shannon-Wiener's index is:

$$
\mathrm{H}=-\sum \mathrm{Pi} \text { Ln Pi }
$$

Where, $\mathrm{H}$ is the index number, $\mathrm{s}$ is the total number of species, $\mathrm{Pi}$ is the proportion of all individuals in the sample which belongs to species $\mathrm{i}$ and $\mathrm{Ln}$ is natural logarithmic value.

Data collected from the field were analyzed using appropriate statistical tools like Microsoft Excel, SPSS: version-13 (Statistical Package for Social Science) software and were sorted as per the different categories. Furthermore, specimens of all species were collected and the herbarium was prepared for identification and was identified in Central Department of Botany and Central Department of Environmental Science, Kirtipur and Botanical Garden, Godawari.

\section{Results and Discussion \\ Socioeconomic and household wellbeing}

The household socio-economic relationship with natural resources extraction had been found to be playing the major role in shaping the conservation measure obliged in the buffer zone areas of Handi Khola VDC. The total population of the sampled household was 460 with an average family size of $6.39 / \mathrm{hh}$ which is higher compared to VDC average (6.18/hh) (DNPWC/PCP 2003). The majority of the ethnic group was Tamangs, Praja, Brahmin/Chhetri, Dalits and Bankariya. Agriculture is the major occupation of the people in the study area. About $78 \%$ of economically active people are engaged in agriculture which was lower to the whole VDC level (99.3\%) given by DNPWC/PCP (2006) and others relied on wage labor, business, remittances etc.
In a study, about $43.06 \%$ households, mostly land rich, had sufficient production from their land to feed their family round the year while food insecurity was more pronounced to Dalit and Indigenous groups. Livestock rearing was the prominent reliance to rural livelihood of Handi Khola Buffer Zone (BZ) population. Livestock unit per household varied in the sampled households according to the land holding and thus Brahmin/Chhetri seemed to rear more livestock than other groups in VDC. Fuelwood is the major energy resources to household of VDC.

\section{Vegetation composition}

The study area comprised two types of forest: Sal forest and Terai Mixed Hardwood Forest. The forest was dominated by Shorea robusta, Mallotus philippinensis, Terminalia alata. Altogether 36 tree species were found representing 19 families. The highest number of species belonging to Leguminoseae family followed by Graminaeae. The total tree density was 252/ha which was lower than the density found by Bhuju and Yonzon (2004) in Churiya of central Nepal. Shorea robusta had the highest density 136.81 /ha representing $54.27 \%$ of total density followed by Mallotus philippinensis (18.75/ha) and Terminalia alata (17.36/ha). In addition, Shorea robusta had higher relative basal area (70.54\%) and highest Important value index (151.70) showing the highest dominancy over other species (Table 1).

The middle layer canopy of forest accounted $11,740.54$ stems/ha and the density of ground vegetation was found to be $1,05,405.4 / \mathrm{ha}$. The stand size classification showed high percent of poles (37.74\%) followed by timber (27.27\%) and sapling (24.79\%) (Fig.3). On comparision, Shree Rakshaniya community forest found to have high well stocked forest (44.44\%), Shree Masine community forest found to have high poorly stocked forest (45.45\%) and the medium stocked forest was found to be high in Shree Dhaneshwor community forest (57.14\%) (Fig.4). 
Aruna Thapa \& Dinesh R. Bhuju/Buffer Zone Resources.....

Table 1. Important Value Index (IVI) of tree species

\begin{tabular}{|c|c|c|c|c|c|c|c|}
\hline Species name & $\begin{array}{c}\mathrm{D} \\
\text { (No./ha) }\end{array}$ & $\begin{array}{l}\mathrm{RD} \\
(\%)\end{array}$ & $\begin{array}{c}F \\
(\%)\end{array}$ & $\begin{array}{l}\text { RF } \\
(\%)\end{array}$ & $\begin{array}{c}\text { BA } \\
\text { (m2/ha) }\end{array}$ & RBA & IVI \\
\hline Shorea robusta & 136.81 & 54.27 & 88.89 & 26.89 & 56.61 & 70.54 & 151.7 \\
\hline Mallotus philippinensis & 18.75 & 7.44 & 19.44 & 5.88 & 1.95 & 2.43 & 15.75 \\
\hline Terminalia alata & 17.36 & 6.89 & 22.22 & 6.72 & 8.2 & 10.22 & 23.83 \\
\hline Lagerstroemia parviflora & 16.67 & 6.61 & 36.11 & 10.92 & 1.25 & 1.56 & 19.09 \\
\hline Schima wallichii & 8.33 & 3.31 & 13.89 & 4.2 & 0.66 & 0.82 & 8.33 \\
\hline Cleistocalyx operculatus & 6.25 & 2.48 & 16.67 & 5.04 & 0.34 & 0.42 & 7.95 \\
\hline Wendlandia puberula & 4.86 & 1.93 & 5.56 & 1.68 & 0.31 & 0.39 & 4 \\
\hline Albizia gamblei & 3.47 & 1.38 & 8.33 & 2.52 & 0.67 & 0.83 & 4.73 \\
\hline Holarrhena pubescens & 3.47 & 1.38 & 2.78 & 0.84 & 1.05 & 1.31 & 3.53 \\
\hline Semecarpus anacardium & 3.47 & 1.38 & 8.33 & 2.52 & 0.53 & 0.66 & 4.56 \\
\hline Careya arborea & 2.08 & 0.83 & 5.56 & 1.68 & 0.32 & 0.4 & 2.91 \\
\hline Ficus semicordata & 2.08 & 0.83 & 5.56 & 1.68 & 0.42 & 0.52 & 3.03 \\
\hline Spondias pinnata & 2.08 & 0.83 & 5.56 & 1.68 & 1.08 & 1.35 & 3.85 \\
\hline Ougeinia oojeinesis & 2.08 & 0.83 & 8.33 & 2.52 & 0.19 & 0.24 & 3.58 \\
\hline Gud* & 2.08 & 0.83 & 8.33 & 2.52 & 0.34 & 0.42 & 3.77 \\
\hline Leea crispa & 2.08 & 0.83 & 5.56 & 1.68 & 0.12 & 0.15 & 2.66 \\
\hline Murraya koenigii & 2.08 & 0.83 & 8.33 & 2.52 & 0.13 & 0.16 & 3.51 \\
\hline Raatigedi* & 2.08 & 0.83 & 2.78 & 0.84 & 1.17 & 1.46 & 3.12 \\
\hline Aesandra butyrea & 1.39 & 0.55 & 5.56 & 1.68 & 0.33 & 0.41 & 2.64 \\
\hline Bridelia retusa & 1.39 & 0.55 & 2.78 & 0.84 & 0.09 & 0.11 & 1.5 \\
\hline Ficus hispida & 1.39 & 0.55 & 5.56 & 1.68 & 0.08 & 0.1 & 2.33 \\
\hline Myrsine semiserrata & 1.39 & 0.55 & 5.56 & 1.68 & 0.47 & 0.59 & 2.82 \\
\hline Premna integrifolia & 1.39 & 0.55 & 2.78 & 0.84 & 0.09 & 0.11 & 1.5 \\
\hline Albizia lucidor & 0.69 & 0.28 & 2.78 & 0.84 & 0.09 & 0.11 & 1.23 \\
\hline Artocarpus lakoocha & 0.69 & 0.28 & 2.78 & 0.84 & 0.03 & 0.04 & 1.15 \\
\hline Cassia fistula & 0.69 & 0.28 & 2.78 & 0.84 & 0.05 & 0.06 & 1.18 \\
\hline Castanopsis indica & 0.69 & 0.28 & 2.78 & 0.84 & 0.35 & 0.44 & 1.55 \\
\hline Dellenia pentagyna & 0.69 & 0.28 & 2.78 & 0.84 & 0.18 & 0.22 & 1.34 \\
\hline Farim* & 0.69 & 0.28 & 2.78 & 0.84 & 0.04 & 0.05 & 1.17 \\
\hline Ficus lacor & 0.69 & 0.28 & 2.78 & 0.84 & 0.03 & 0.04 & 1.15 \\
\hline Litsea monopetala & 0.69 & 0.28 & 2.78 & 0.84 & 0.03 & 0.04 & 1.15 \\
\hline Michelia champaca & 0.69 & 0.28 & 2.78 & 0.84 & 2.74 & 3.41 & 4.53 \\
\hline Sterculia villosa & 0.69 & 0.28 & 2.78 & 0.84 & 0.07 & 0.09 & 1.2 \\
\hline Terminalia bellirica & 0.69 & 0.28 & 2.78 & 0.84 & 0.04 & 0.05 & 1.17 \\
\hline Trewia nudiflora & 0.69 & 0.28 & 2.78 & 0.84 & 0.18 & 0.22 & 1.34 \\
\hline Woodfordia fruticosa & 0.69 & 0.28 & 2.78 & 0.84 & 0.02 & 0.02 & 1.14 \\
\hline Total & 252.08 & 100 & 330.56 & 100 & 80.25 & 100 & 300 \\
\hline
\end{tabular}

*= Local name. $\mathrm{D}=$ Density, $\mathrm{RD}=$ Relative Density, $\mathrm{F}=$ Frequency, $\mathrm{RF}=$ Relative Frequency, $\mathrm{BA}=$ Basal Area, RBA= Relative Basal Area, IVI= Important Value Index, ha $=$ Hectare

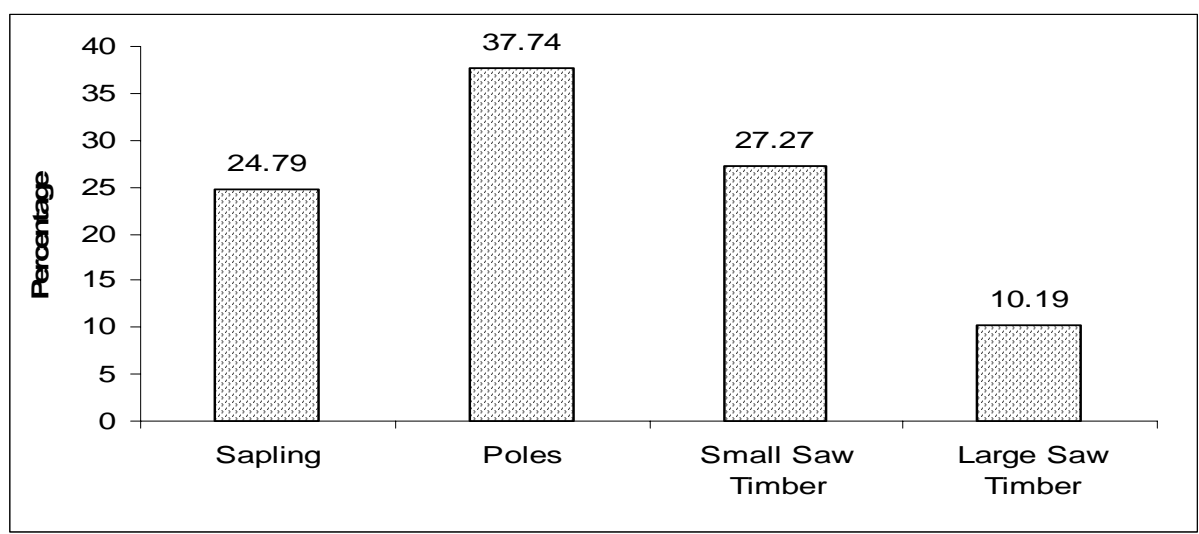

Fig.3. Stand size classification of trees 


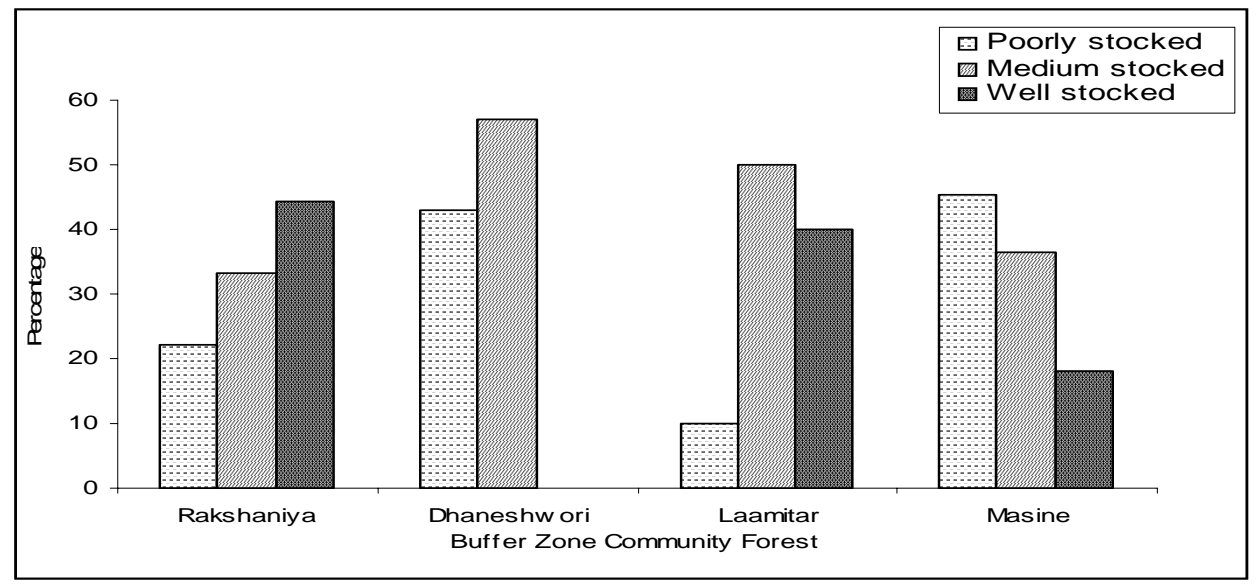

Fig. 4. Percentage of stocking of tree species in a plot by community forest

\section{Forest status}

The status of forest was analyzed by computing different index of plant distribution. The species in tree and shrub strata had the higher Dominance Index and low Diversity index than the species in herb stratum showing the presence of some dominant species in case of tree and shrub species controlling influence in the whole community i.e. few species are dominant in the tree and shrub strata decreasing the evenness and diversity index. However, the species richness was found to be higher in case of shrub strata (Table 2).

Table 2. A comparative analysis of dominance index, species richness, Shannon diversity index and evenness index

\begin{tabular}{|c|c|c|c|c|c|c|c|c|c|c|c|c|}
\hline \multirow{2}{*}{ Parameters } & \multicolumn{3}{|c|}{ Shree Rakshaniya } & \multicolumn{3}{|c|}{ Shree Dhaneshw or } & \multicolumn{3}{|c|}{ Shree Laamitaar } & \multicolumn{3}{|c|}{ Shree Masine } \\
\hline & $\mathbf{T}$ & $\mathbf{S}$ & $\mathbf{H}$ & $\mathbf{T}$ & $\mathbf{S}$ & $\mathbf{H}$ & $\mathbf{T}$ & $\mathbf{S}$ & $\mathbf{H}$ & $\mathbf{T}$ & $\mathbf{S}$ & $\mathbf{H}$ \\
\hline Do & 0.18 & 0.25 & 0.09 & 0.23 & 0.13 & 0.09 & 0.63 & 0.26 & 0.12 & 0.31 & 0.12 & 0.07 \\
\hline $\mathrm{SR}$ & 8.8 & 13.25 & 8.31 & 7.4 & 11.96 & 6.54 & 4.35 & 5.87 & 5.65 & 8.46 & 13.46 & 12.08 \\
\hline $\mathrm{H}$ & 0.93 & 0.98 & 1.15 & 0.88 & 1.19 & 1.09 & 0.41 & 0.84 & 0.98 & 0.79 & 1.16 & 1.29 \\
\hline e & 0.73 & 0.62 & 0.87 & 0.77 & 0.79 & 0.95 & 0.41 & 0.68 & 0.85 & 0.65 & 0.73 & 0.86 \\
\hline
\end{tabular}

The density of lopped trees and cut stump substantiated the evidence of human pressure on forests. The total density of cut stump was 39.56/ha which was less than study of Paudyal (2007) i.e. 107.7/ ha. Shorea robusta (18.75/ha) found to be highly cut followed by Mallotus phillippinensis and Terminalia alata (4.17/ha) each. This is because Shorea robusta is considered the most valuable tree species and is used in construction and carpentry work, and is the main source of fuelwood in this BZ area. Majority of cut stump were in girth size $12.5-25 \mathrm{~cm}$
(CSD: 18.06/ha), this is because of usage of these stand size trees in house building purpose and sheds of animals as well as preferred as fodder species by the locals. The density of lopping damage to tree was 58.11/ha. Shorea robusta, Mallotus philippinensis, Terminalia alata were the most common species lopped among others.

\section{Standing volume, biomass and sustainable yield of tree species}

The total standing volume and total biomass was found to be $42.57 \mathrm{~m}^{3} / \mathrm{ha}$ and $62,508.65 \mathrm{~kg} / \mathrm{ha}$ 
respectively which were lower than $467 \mathrm{~m}^{3} / \mathrm{ha}$ and 8,07,000 Kg/ha that found in Shrestha et al. (2000) in natural Sal forest in Chitrepani of Makawanpur district, while this values were higher compared to Subedi (2010) that found standing volume and biomass to be $31.87 \mathrm{~m}^{3} /$ ha and 39.12 tons/ha respectively. Similarly, average biomass as reported by HMG/N (1988a) of Central Development Region (1,48,870 Kg/ha) was higher to accumulate biomass in Handi Khola BZ forest. Out of 36 tree species, Shorea robusta had the highest percentage of standing volume and biomass (67.58\% and 56.90\%) followed by Terminalia alata (10.22\% and 10.98\%), Michelia champaca (5.37\% and $3.19 \%)$.

The forest could supply $2457.88 \mathrm{~kg} / \mathrm{ha} / \mathrm{yr}$ of fuel wood, $258.91 \mathrm{~kg} / \mathrm{ha} / \mathrm{yr}$ of timber and $91.02 \mathrm{~kg} / \mathrm{ha} / \mathrm{yr}$ of foliage in sustainable way (Table 3). This value of fuel wood was higher than Paudyal (2007), Shrestha (2007) and Subedi (2010); these were 1,966.7, 520 and 1458.81 respectively but less than Sharma (2009) that was 4211 $\mathrm{kg} / \mathrm{ha} / \mathrm{yr}$. Shorea robusta had the highest supply of all resources followed by Aesandra butyrea, Terminalia alata. The sustainable yield of forest resources seemed failed for fulfilling the household demand in case of Paudyal (2007), Shrestha (2007) and Subedi (2010). But in contrast them, this present study reveals the sustainable supply of both fuel wood and timber from the forest, however, it was estimated annual deficit of 9231.13 tons/yr of green fodder at Handi Khola BZ VDC directing its household fulfilling their demand from their own agricultural land as well as user's dependency on reserves too.

Table 3. Estimated resource supply and demand

\begin{tabular}{|c|c|}
\hline Parameters & Value \\
\hline F orest area (ha) & 1204.15 \\
\hline T otal no. of $\mathrm{HHs}$ in Haadikhol a BZ area $(5,6 \&$ \& 7 wards) & 1160 \\
\hline Estim ated no. of $\mathrm{HH}$ using fuel wood & $1144 *$ \\
\hline Estim ated no. of $\mathrm{HH}$ using fodder & $1063^{* *}$ \\
\hline Sustainable Fuel wood from V DC ( $t / y$ r) & 2959.65 \\
\hline T otal Dem and of Fuel wood (t/yr) & 2644.93 \\
\hline Fuel wood surp hus $(t / y r)$ & 314.72 \\
\hline Sustainable Green Fodder yield from forests of V DC (TDN in tonstyr) & $409.41 \#$ \\
\hline $\begin{array}{l}\text { T otal Household Green } F \text { odder need }(t / y) \\
\text { Deficit Green F odder }(t / y r)\end{array}$ & $\begin{array}{r}9640.54 \\
\mathbf{- 9 2 3 1 . 1 3}\end{array}$ \\
\hline
\end{tabular}

*= Out of 72 households, 71 households used Fuel wood for cooking purposes. So, 1144 (98.61\% of 1160) were using Fuel wood.

**= Out of 72 households, 6 households didn’t have livestock. This shows $91.67 \%$ of total households need fodder. So, 1063(91.67\% of 1160) households were using fodder.

\#= This value only shows the total fodder supply from forest using TDN value $(0.34 \mathrm{t} / \mathrm{ha} / \mathrm{yr})$, but for the fodder demand the households used their agricultural field and most of households used to graze their livestock to fulfill their demand

\section{Acknowledgements}

We are grateful to late Dr Pralad Yonzon for valuable suggestions. Resources Himalaya Foundation provided mentorship grant to the first author. Acknowledgements are highly accorded to all the members of CFUGs and local people who provided valuable information and to Environment Graduates Himalaya founder for data analysis and map preparation using GIS.

\section{References}

Arkin, H. and R. R. Colton. 1963. Tables for statisticians. New York: Barnes \& Noble.

Budhathoki, P. 2005. Royal Chitwan National Park: A World Heritage Site with Buffer Zone. In: People and Protected Areas in South Asia (Eds. U.R. Sharma and P.B. Yonzon). Resources Himalaya and World Conservation Union. 
Nepal Journal of Science and Technology 12 (2011) 230-237

Bhuju, D.R. and P.B. Yonzon. 2004. Species maintenance in a dynamic landscape: Ecology of the Churia (Siwaliks) in Nepal Himalaya. In: Annual Report of Pro Natura Fund 13:155-175.

DNPWC/PCP. 2003. Parsa Wildlife Reserve and proposed Buffer Zone, Resource Profile. Department of National Park and Wildlife Conservation. HMG/N/PCP/UNDP. Kathmandu, Nepal.

DNPWC/PCP. 2006. Management Plan of Parsa Wildlife Reserve and its Buffer Zone (2006-2010). Department of National Park and Wildlife Conservation/ Participatory Conservation Programmme II. Kathmandu, Nepal.

DNPWC. 2009. Annual Report Published by Department of National Parks and Wild Life Conservation. Kathmandu Nepal.

FSSD. 1991. Volume equation and biomass prediction of forest trees of Nepal. Forest Survey and Statistical Division. Ministry of Forest and Soil Conservation, Publication No. 47. Kathmandu. Nepal.

HMG/N. 1988a. Forest Resource Information and Status and Development Plan. Master Plan for the Forestry Sector of Nepal. The then His Majesty's Government of Nepal (Now Government of Nepal). Ministry of Forest and Soil Conservation, Kathmandu, Nepal.

Kent, M. and P. Coker. 1998. Vegetation Development and Analysis: A practical Approach. John Wiley and Sons, New York City.

MoFSC, 1988. Master Plan for Forestry Sector Nepal: Forest Resources Information, Status and Development Plan. Kathmandu, Nepal.
Odum, E.P. 1996. Fundamentals of Ecology. W.B. Saunders Company, USA.

Paudyal, A. 2007. Buffer Zone Resources and Community Conservation: A case study of Piple BZ VDC, Chitwan National Park. M.Sc. Thesis. Central Department of Environmental Science, Tribhuvan University, Kathmandu, Nepal.

Sharma, B. K. 1995. An Assessment of Crop Damage by Wild Animals and Depredation of the Wildlife due to the Activities of Local People in Koshi Tappu Wildlife Reserve. M. Sc. Thesis. Central Department of Zoology, Tribhuvan University, Kathmandu, Nepal.

Shrestha, D.B. 2007. Buffer Zone Resources, Livelihood and Conservation Practices in Kumroj Buffer Zone VDC, Chitwan National Park. M.Sc. Thesis, Central Department of Environmental Science, Tribhuvan University, Kathmandu, Nepal.

Shrestha R., S.B. Karmacharya and P.K. Jha. 2000. Vegetation analysis of natural and degraded forests in Chitrepani in Siwalik region of Central Nepal. Tropical Ecology 41(1): 111-114.

Subedi, G. 2010. Buffer Zone Resources, Livelihood and Community Level Conservation: A Case Study from Jyamire Buffer Zone Community Forest, Manahari VDC, Parsa Wildlife Reserve. M.Sc. Thesis. Central Department of Environmental science. Tribhuvan University, Kathmandu, Nepal.

Wyne, G. 1998. Conservation Policy and Politics. In: Conservation, Science and Action (Ed. W.J. Sutherland). Blackwell Science, Oxford, pp. 256-285. 